\title{
Evolution of the Iowa High School
}

\author{
By L. F. Parker ${ }^{\circ}$ \\ Professor of History, Iowa College
}

Massachusetts is proud of her early educational history. That pride is honorable. When only six years old, Massachusetts Bay colony founded Harvard college, eight years later she commanded all householders to give their children and apprentices a primary education, and five years after that she threatened to impose a fine of $\$ 25$ annually upon every township of one hundred families which should fail to maintain a complete fitting school for the university. The order is noteworthy-university first, primary schools next, and secondary schools last.

The people of what is now Iowa, like Massachusetts, maintained schools without law, and before the school law, but the earliest specific provision for them in this territory was the incorporation of seven academies and two colleges by the legislature of Wisconsin territory. That recognition of school ambitions on Iowa soil was given in a single week in January, 1838, some six months before the organization of Iowa territory, and less than five years after the Black Hawk purchase was thrown open to the white settlement. That legislation stands as an honorable record of Iowa's aspirations when its entire white population was only about onethird of that of Des Moines of today, and was so widely scattered as to represent about one person to a square mile.

Nevertheless, the institutions so incorporated died at their birth hour, or in earliest infancy, but they indicated a widely diffused and high minded purpose to make early provision for secondary education. That purpose led to the creation and support of still other academies during the territorial period. Of these, sev-

-From manuscript collection, Iowa State Department of History and Archives. Filed April 1, 1899. 
eral "died young," as is said to be common with the "good." Denmark academy alone survives in defiance of the proverb.

Even when Iowa became a state, there could be no urgent demand in any one locality for secondary studies in the public schools. Pioneer necessities made it unwise for any rural district to carry its education much, if any, above the common branches, but some towns were then large enough to demand more than one school room.

In 1848, Thomas $\mathrm{H}$. Benton, Jr., state superintendent of public instruction, recommended that schools should be graded wherever gradation was practicable. Muscatine carried out that suggestion in 1851, under the able leadership of George B. Dennison, and placed D. Franklin Wells (soon to be first professor in the normal department of the State university, and then state superintendent) at the head of the second graded school in 1853. Strong men in the school room, and out of it, insured steady progress.

Tipton and Grinnell Opened Union Schools

Tipton placed C. C. Nestlerode at the head of her graded school in her new school building in 1856. He earned the title of "The Organizer and Defender of the Tipton Union School." With the warmth of an Irishman, the pertinacity of a Scotchman, the zeal of the Psalmist and the directness of a Cromwell, he moved in knightly armor among "school killers" and school builders through six fiery years. Wherever he went, he was the apostle and the reformer, an educational Cid. Few patrons were zealous enough for him, and few teachers were aggressive enough. Slower natures thought Tipton was doing very well. $\mathrm{He}$ could not think so. He withdrew from the school room and from Iowa in 1862, followed by the love of the pupils, the regrets of patrons, and the admiration of his fellow teachers in the state.

Grinnell opened her Union School in 1856, a little before Tipton began hers, but that seemed to all con- 
cerned the most natural thing in the world. The first school building erected in the town was for a graded school, and classes moved from room to room and into secondary studies without a word of objection from any source. In purpose it was the preparatory department of a prospective Grinnell university; in fact, it was introductory to Iowa college.

During the years 1857 and 1858, Iowa was made memorable by its exchange of the rate bill system for a well rounded free school law. During its first dozen years of statehood, its entire population became about six times as numerous as at first, and its school enumeration about fifteen times as great. At the end of that time it was possible for it to assume something of the dignity and the stability of a settled, rather than of settling, state. More distinct legal provision was then made for instruction in the higher branches, and for schools of a higher grade, at the option of the people of any district.

From counties where graded schools existed, lawmakers went to the legislature prepared to sustain provisions in their favor. It is said that representatives from Cedar county carried such a bill in their pockets, one prepared by our educational "Count Nestlerode." With such prophets of education as James W. Grimes in the governor's chair, J. B. Grinnell chairman of the senate committee on schools, and as William G. Thompson of Linn county, Jonathan W. Cattell of Cedar, Alvin Saunders of Henry, Samuel F. Cooper of Poweshiek, and others in the legislature and on the board of education, legal permission to districts to create schools of higher grades was obtained very readily, and it was permission that was needed.

\section{County High Schools Next}

County high schools, to serve the double purpose of academies and of normal schools, were authorized by the legislature in the early months of 1858. State Superintendent Fisher urged the counties to establish them. City Superintendent Kissell of Davenport and 
others aroused some desire to open them in Scott and in other counties. Later in the year, the first convention of county superintendents declined to urge or to endorse the movement at that time, and in December the board of education suspended all further effort in their favor by making no provision for them in the school law which they enacted.

But even at that time graded schools in towns were usually crowned by the "high school," so called, a title given by brevet or as a prophecy. Ten years later the number of graded schools had risen to 212, and the "high schools" had become materially higher. The earliest gradation of schools rarely implied the distinct purpose to carry them far into, or beyond, preparation for college. Gradation was good, even if instruction did not extend beyond the grammar school. But a local demand arose in the larger and more intelligent communities for the more advanced studies.

That unwise introduction of higher branches into the lower schools did not pass unnoticed, and, indeed, was not limited to the long ago. Superintendent Von Coelln made an earnest protest against it; Superintendent Sabin has repeated that warning. It attracted widespread attention.

It is fortunate in human history that often, perhaps usually, remedies grow side by side with the evils which they are adapted to cure. We may call the ten years, beginning with 1870, "the high school decade," for during that time college and state university ambitions were mingling with those graded school ambitions and moulding high schools. The proper work of the high school was earnestly and widely discussed by teachers of public and private schools.

Unstable and Backward Districts

It was not very difficult to conclude that many graded schools did not reach up to the high school, hence Superintendent Kissell could say in 1871 that there were 289 graded schools in the state, and only forty high schools. It was easy also to accept the ninth 
grade of school work as the first year of high school, but Superintendent Kissell suggested a harder problem when he said that only twenty-three of the forty high schools in 1871 had "well defined courses of study." Ill-defined and unstable school districts were aroused; local ideas were formulated; courses of study ceased to be the creation of individual caprice and began to represent local choice, enlightened by public discussion.

Some districts encountered a varying difficulty. Most of their students ended their school work in the high school or before; a few desired to go to college. "Can and shall the high school give the necessary preparation?" The answer to this question in the state was a vital one to the State university, for it was required by law to begin its course in the collegiate department where the high schools left off.

It was important to the colleges also, for their officers hoped for a liberal supply of students from the upper classes of the public schools. In the State Teachers' association it was the theme for lectures, papers and debates by teachers in public and private schools. They wrestled with it and with each other. A common goal was before them. The optimistic anticipated an impossible success; the pessimistic lamented prospects of failure to attain the ideal. The pessimism and the optimism were alike helpful. The teachers in the stronger districts carried home an echo from the association.

The master minds over the state weighed the diverse views and turned to high school expansion with a zeal somewhat measurable by the fact that while the state was adding 36 percent to its population, it nearly doubled its expenditures for schools, and far more than doubled them in provision for the higher branches. In that decade the state fairly entered on the work for secondary education, which is so noticeable and so creditable, a work which has resulted in the admission of large numbers of students to college classifi- 
cation on certificates from high school teachers. High school courses, however, are not even yet uniform, and never will be so long as local preferences control them.

The State Teachers' association has given wise recommendations and had noteworthy influence, but the curricula of colleges continue to be the supreme modifying force in the secondary work of the high. schools in their immediate vicinity, while high school interests have changed college courses. College influence has stimulated the study of Latin in the high schools, and high schools have forced Greek out of the studies preparatory to the State university, and are still forcing sub-freshman Latin into special classes in its recitation rooms.

\section{Opposition Over-Taxed Patience}

The historian cannot overlook the fact that this evolution of the high school has brought grief to some. The journals of the time preserve the evidence of the sorrow of a very good man occasionally, and the opposing efforts of some, possibly not so good. The strange interpolation in President Grant's Des Moines speech in 1875, which transformed his advocacy of common schools into an attack upon all public school work above common schools, will long remain a striking example of falsification of a semi-state paper, which lacked little of complete success. Another note from that microscopic opposition to high schools appeared in Harper's Monthly Magazine as late as July, 1889, when an eminent American and former Iowan wrote:

It is becoming a question, and a grave one in the state, whether these high schools are not a violation of the spirit and purpose of the school law.

That mountain which he, as far away as Washington, could see, seemed to people resident in Iowa the smallest of mole hills.

After all, the barriers to the evolution of the high school, comparatively slight as they have been, have demanded wisdom, taxed patience, and at times, chilled enthusiasm, but they have ensured delibera- 
tion, a more pronounced public expression in its favor, and the permanence of every useful advance in its scope or its methods.

\title{
A Tribe of Chippewa Indians
}

\author{
By O. J. Prurtr
}

In 1938, when the Pottawattamie, Ottawa and Chippewa Indians were removed from Fort Dearborn (Chicago), Waubanse was made chief over all three tribes. Waubanse preferred Mills and Fremont counties as residences, but Sagonah, a halfbreed, and Willamete selected Millers Hollow, now Council Bluffs, because of the blockhouse erected for protection of these tribes against the Sioux.

This blockhouse later was given to Father P. J. DeSmet for a church, where it is thought he converted both Sagonah and Willamete. Their bones were excavated when it was necessary to open Franklin Avenue in Council Bluffs. These bones were then reinterred in the Catholic cemetery and marked "Indians." Many of the squaws were taught the white man's religion. One of these was the wife of the famous bullwhacker, John Y. Nelson, who in after years piloted Brigham Young to Salt Lake. This same man later drove the stage coach in the famous Buffalo Bill Wild West show. Three of his children, who were halfbreeds, clung to the iron railing on top of the coach, while it bounced around the arena over the rough terrain. The writer saw the first performance given in Council Bluffs many years ago.

The Chippewa Indians, under the leadership of Pacha (pronounced Paw-shay) chose a hunting ground near Neola and pitched seven government waterproof tents in the grove known as Pattee Grove. Mr. Pattee was an Englishman and had a number of trotting horses which he trained on his own half-mile oval track. High waters of the creek washed away the 
Copyright of Annals of Iowa is the property of State of Iowa, by \& through the State Historical Society of Iowa and its content may not be copied or emailed to multiple sites or posted to a listserv without the copyright holder's express written permission. However, users may print, download, or email articles for individual use. 